\title{
PENGARUH VARIASI LAMA PENYIMPANAN REAGEN ENZIM 1a TERHADAP HASIL PEMERIKSAAN UREUM DARAH METODE BERTHELOT
}

\author{
${ }^{1}$ Rahmi Nur Fahisyah, ${ }^{2}$ Nurlia Naim, ${ }^{3}$ Zulfian Armah \\ 1,2,3 Jurusan Analis Kesehatan Poltekkes Kemenkes Makassar
}

Koresponden: nurlianaim0416@gmail.com

\begin{abstract}
ABSTRAK
Pemeriksaan ureum dengan menggunakan reagen enzim 1a merupakan uji yang sering digunakan oleh para klinisi, teknik laboratorium sangat berpengaruh terhadap hasil pemeriksaan ureum, namun kesalahan yang biasa dilakukan oleh para klinisi yaitu sering membuat reagen yang berlebihan sehingga mengalami penyimpanan. Penelitian ini dilaksanakan di laboratorium Kimia Klinik Analis Kesehatan. Tujuan penelitian ini adalah untuk mengetahui pengaruh lama penyimpanan reagen enzim 1a terhadap hasil pemeriksaan ureum darah metode berthelot. Jenis penelitian ini bersifat eksperimen semu dimana sampel pemeriksaan yang digunakan dalam penelitian ini sebanyak 3 sampel. Data hasil penelitian dianalisa dengan menggunakan uji analysis of variance (Anova). Setelah dilakukan penelitian didapatkan hasil bahwa $F_{\text {hitung }}(44,49)>F_{\text {tabel }}($ 5,14 ) pada $\alpha 0.05$ berarti ho ditolak dan Ha diterima, yang menunjukkan bahwa ada pengaruh yang bermakna antara lama penyimpanan reagen enzim 1a terhadap hasil pemeriksaan ureum darah metode berthelot, sehingga dapat ditarik kesimpulan bahwa lama penyimpanan reagen enzim 1a pada suhu ruangan berpengaruh terhadap hasil pemeriksaan kadar ureum.
\end{abstract}

Kata Kunci : Lama Penyimpananan, Metode Berthelod, Reagen Enzim 1a, Ureum

\begin{abstract}
ABSTRACK
Examination of urea by using enzyme reagent $1 a$ is a test that is often used by clinicians, laboratory techniques are very influential on the results of urea examination, but the usual mistake made by the clinician is often making excessive reagents so storage. This research was conducted in Chemistry Laboratory of Clinical Analyst Health. The purpose of this study is to determine the effect of storage duration of enzyme la reagent on blood ureum test of berthelot method. This type of research is a quasi experiment where the sample examination used in this study as many as 3 samples. The data of the research were analyzed by using analysis of variance (ANOVA). After the research, it was found that Fcount $(44,49)>F$ table $(5,14)$ at $\alpha$ 0.05 means ho rejected and Ha accepted, indicating that there is a significant influence between the storage period of enzyme reagent la to the result of blood ureal examination of berthelot method, so it can be concluded that the duration of storage
\end{abstract}


of enzyme la reagents at room temperature has an effect on the result of urea concentration

Keywords : Berthelod Method, Long Storage,Reagen Enzim 1a, Ureum

\section{PENDAHULUAN}

Ginjal termasuk salah satu organ tubuh manusia yang vital. Organ ini berperan penting dalam metabolisme tubuh seperti fungsi ekskresi, keseimbangan air dan elektrolit, serta endokrin. Fungsi ginjal secara keseluruhan didasarkan oleh fungsi nefron dan gangguan fungsi ginjal disebabkan oleh menurunnya nefron. Penyakit ginjal sering disertai penyakit lain yang mendasarinya seperti diabetes melitus, hipertensi dislipidemia, dan lain-lain. Gejala gangguan ginjal stadium dini cenderung ringan, sehingga sulit didiagnosis hanya dengan pemeriksaan klinis. Pemeriksaan laboratorium dapat mengidentifikasi gangguan fungsi ginjal lebih awal. Pemeriksaan antara lain kadar ureum, hal ini dapat membantu dokter klinisi dalam mencegah dan tatalaksana lebih awal untuk mencegah gangguan ginjal menjadi gagal ginjal (Verdiansah, 2016)

Ureum merupakan hasil akhir metabolisme protein. Berasal dari asam amino yang telah dipindah amonianya di dalam hati dan mencapai ginjal, dan diekskresikan rata-rata 30 gram sehari. Kadar ureum darah yang normal adalah $30 \mathrm{mg}$ setiap $100 \mathrm{cc}$ darah, tetapi hal ini tergantung dari jumlah normal protein yang dimakan dan fungsi hati dalam pembentukan ureum (Andriyani,R.dkk 2015).
Di beberapa laboratorium rumah sakit atau laboratorium klinik biasa menggunakan reagen kerja (campur), hasil dari preparasi reagen dalam skala besar ini, diperuntukkan atau dilakukan agar dalam pemeriksaan kimia darah didapatkan pelaksanaan kerja yang cepat, efisien dan efektif.

Pada pemeriksaan di Laboratorium ada beberapa faktor kesalahan yang mungkin terjadi yang dapat mempengaruhi hasil pemeriksaan, diantaranya faktor reagen, alat, metode, SDM, dan sampel (Depkes, RI 2008)

Tujuan penelitian ini adalah untuk mengetahui pengaruh lama penyimpanan reagen enzim 1a terhadap hasil pemeriksaan ureum darah metode Berthelot di Laboratorium Analis Kesehatan Poltekkes Makassar.

\section{METODE}

\section{Desain, tempat dan waktu}

Jenis penelitian ini adalah eksperimen semu (quasy experiment) yang bertujuan untuk mengetahui pengaruh variasi lama penyimpanan reagen enzim 1a terhadap hasil pemeriksaan ureum metode Berthelot. Penelitian dilakukan di Laboratorium Kimia Klinik jurusan Analis Kesehatan Politeknik Kesehatan Makassar. Penelitian ini telah dilakukan di Laboratorium Analis Kesehatan Poltekkes Kemenkes Makassar bulan Februari - Maret 2018 


\section{Bahan dan Alat}

Spektrofotometer 5010, Klinipet $10 \mu 1$, $100 \mu \mathrm{l}, 1000 \mu \mathrm{l}$, Rak tabung reaksi, Tabung reaksi, Tip biru dan kuning, Timer, Sentrifus, Tissue

\section{Bahan : Serum normal \\ Reagen : Urea liquicolor kit}

Persiapan reagen :

RGT2 dan STD siap untuk digunakan

Reagen enzim 1a disiapkan dengan mencampur isi botol ENZ dengan isi botol RGT1, misalnya

$\begin{array}{ccc}1 \mathrm{ml} \mathrm{ENZ} & + & 100 \mathrm{ml} \mathrm{RGT1} \\ & \begin{array}{c}\text { atau } \\ +\end{array} & 1000 \mathrm{ml} \mathrm{RGT1}\end{array}$

\section{Prosedur Kerja}

Prosedur pemeriksaan kadar ureum :

Disiapkan alat dan bahan yang bersih dan kering, disusun tabung reaksi, masing-masing untuk tabung sampel, standar, blanko dan kontrol, dipipet reagen enzim 1a, masing-masing 1000 $\mu \mathrm{l}$ dan dimasukkan kedalam tabung sampel, standar, dan blanko, untuk tabung sampel dipipet serum sebanyak $10 \mu \mathrm{l}$ dan standar $10 \mu \mathrm{l}$ dimasukkan pada tabung standar, dicampur dan inkubasi selama 5 menit pada suhu 20 $25^{\circ} \mathrm{C}$, ditambahkan masing-masing reagen 2 (RGT2) $1000 \mu 1$ pada tabung sampel, standar, dan blanko, dicampur dan diinkubasi pada suhu $20-25^{\circ} \mathrm{C}$ selama 10 menit, dibaca pada alat spektrofotometer 5010 dengan panjang gelombang $578 \mathrm{~nm}$. Dari hasil pemeriksaan ureum dilakukan perhitungan

Ket: faktor urea Serum/plasma = $80 \mathrm{mg} / \mathrm{dl}$ atau $13,3 \mathrm{mmol} / \mathrm{l}$

Nilai normal $=10-50 \mathrm{mg} / \mathrm{dl}$ atau 1,7 $-8,3 \mathrm{mmol} / \mathrm{l}$

Pengolahan dan analisis data

Data yang diperoleh akan dilakukan dengan perhitungan Uji Statistik dengan menggunakan analysis of variance (Anova).

\section{HASIL}

Berdasarkan hasil penelitian yang dilaksanakan mulai tanggal 12-26 Februari 2018 di Laboratorium Kimia Klinik Analis Kesehatan Makassar tentang pengaruh variasi lama penyimpanan reagen enzim 1a terhadap hasil pemeriksaan ureum darah metode Berthelot dengan jumlah 3 sampel, maka diperoleh hasil sebagai berikut :

Tabel 1 : Hasil Pemeriksaan Ureum yang dilakukan

\begin{tabular}{ccccc}
\hline Kode & $\begin{array}{c}\text { Jumlah } \\
\text { Replikasi }\end{array}$ & \multicolumn{3}{c}{$\begin{array}{c}\text { Hasil Pemeriksaan } \\
\text { Ureum Darah (mg/d) }\end{array}$} \\
\cline { 2 - 5 } & & Segera & $\mathbf{7}$ hari & $\mathbf{1 4}$ hari \\
\hline A & 1 & 24 & 25 & 240 \\
& 2 & & 27 & 234 \\
& 3 & & 26 & 275 \\
& 4 & & 28 & 233 \\
& 5 & & 30 & 257 \\
6 & & 27 & 243 \\
& 7 & & 29 & 283 \\
\hline
\end{tabular}




\begin{tabular}{|c|c|c|c|c|}
\hline & \multicolumn{2}{|l|}{8} & 27 & 242 \\
\hline & \multicolumn{2}{|l|}{9} & 25 & 235 \\
\hline & \multicolumn{2}{|l|}{10} & 27 & 251 \\
\hline & \multicolumn{2}{|l|}{11} & 26 & 273 \\
\hline \multirow[t]{11}{*}{ B } & 1 & \multirow[t]{11}{*}{33} & 33 & 134 \\
\hline & 2 & & 35 & 141 \\
\hline & 3 & & 32 & 187 \\
\hline & 4 & & 35 & 183 \\
\hline & 5 & & 35 & 189 \\
\hline & 6 & & 33 & 171 \\
\hline & 7 & & 35 & 168 \\
\hline & 8 & & 32 & 173 \\
\hline & 9 & & 34 & 152 \\
\hline & 10 & & 32 & 143 \\
\hline & 11 & & 35 & 152 \\
\hline \multirow[t]{11}{*}{$\mathrm{C}$} & 1 & \multirow[t]{11}{*}{32} & 38 & 201 \\
\hline & 2 & & 33 & 173 \\
\hline & 3 & & 40 & 192 \\
\hline & 4 & & 41 & 217 \\
\hline & 5 & & 42 & 207 \\
\hline & 6 & & 42 & 225 \\
\hline & 7 & & 42 & 180 \\
\hline & 8 & & 38 & 208 \\
\hline & 9 & & 38 & 188 \\
\hline & 10 & & 40 & 182 \\
\hline & 11 & & 42 & 225 \\
\hline
\end{tabular}

Berdasarkan tabel 1 didapatkan bahwa

kenaikan yang signifikan yaitu pada 14 rata-rata kadar ureum darah mengalami hari penyimpanan reagen enzim

Tabel 2 : Hasil Analisis Uji One-Way Anova Data Hasil Pemeriksaan

\begin{tabular}{ccccccc}
\hline Perlakuan & $\mathbf{N}$ & $\begin{array}{c}\text { Mean } \\
(\mathbf{X})\end{array}$ & $\begin{array}{c}\text { Std.deviation } \\
(\mathbf{S D})\end{array}$ & & \\
\cline { 5 - 6 } & & & & & \\
Segera & 3 & 29.67 & 4.933 & & \\
7 hari & 3 & 33.67 & 6.506 & 44,48 & 5,14 \\
14 hari & 3 & 204.67 & 44.185 & & \\
Total & 9 & 89.33 & 89.387 & & \\
\hline
\end{tabular}

Berdasarkan hasil uji One-Way Anova menunjukkan bahwa nilai $F_{\text {hitung }}(44,48)>F_{\text {tabel }}(5,14)$. Berarti ho ditolak dan Ha diterima, yang menunjukkan ada pengaruh yang bermakna antara lama penyimpanan 
reagen enzim 1a terhadap hasil pemeriksaan ureum darah metode berthelot.

\section{PEMBAHASAN}

Pemeriksaan ureum merupakan pemeriksaan fungsi ginjal dengan test urea secara kinetika enzimatis dan menginterpresentasikan hasil pemeriksaan yang diperoleh. Ureum dapat dijadikan salah satu parameter kerusakan ginjal karena merupakan hasil akhir metabolisme protein didalam hati, dimana ammonia bereaksi dengan karbon dioksida $\left(\mathrm{CO}_{2}\right)$ hasil respirasi sel dalam tubuh akan menghasilkan ureum yang mencapai ginjal dan dieksresi rata-rata 30 gram sehari.

Prinsip pemeriksaan ureum dengan metode kolorimetRi adalah urea dihidrolisis oleh urease menjadi amonia dan karbOn dioksida.

$$
\text { Urea }+\mathrm{H}_{2} \mathrm{O} \stackrel{\text { urease }}{\longrightarrow} 2 \mathrm{NH}_{3}+\mathrm{CO}_{2}
$$$$
\mathrm{NH}_{2}+\alpha-\mathrm{KG}+\mathrm{NAHD}+\mathrm{H}^{+\mathrm{GDLH}}
$$

Pada pemeriksaan ureum metode yang sering digunakan oleh laboratorium klinik adalah metode berdasarkan reaksi enzimatik. Suatu reaksi enzimatik dipengaruhi oleh beberapa faktor seperti $\mathrm{pH}$ atau keasaman, konsentrasi enzim, substrat dan kofaktor, inhibitor enzim.

Pada reagen kerja terdapat substrat. Dimana lama penyimpanan akan mempengaruhi bentuk substrat, sehingga pada proses pencampuran antara reagen kerja dan sampel serum tidak terjadi pengikatan yang sempurna antara substrat dan enzim. Ketidaksempurnaan reaksi antara reagen dan serum berakibat
Kemudian amonia bebeaksi dengan alkali hipoklorit dan sodium salisIlat dengan adanya sodium nitropusid membentuk warna kompleks berwarna hijau, intensitas warna yang terbentuk sebanding dengan kadar ureum dalam sampel, dan dibaca pada s`ektrofotometer 5010 dengan panJang gelombang $546 \mathrm{~nm}$.

Hasil uji One-Way Anova terhadap pengaruh variasi lama penyimpanan reagen enzim 1a terhadap hasil pemeriksaan ureum darah metode barthelot menunjukkan bahwa nilai $F_{\text {hitung }}(44,48)>F_{\text {tabel }}(5,14)$. Berarti ho ditolak dan $\mathrm{Ha}$ diterima, yang menunjukkan ada pengaruh yang bermakna antara lama penyimpanan reagen enzim 1a terhadap hasil pemeriksaan ureum darah metode berthelot.

Adapun reaksi yang terjadi pada pemeriksaan ureum

$$
\text { L-Glutamate }+\mathrm{NAD}^{+}+\mathrm{H}_{2} \mathrm{O}
$$

meningkatnya hasil pemeriksaan ureum dari hari kehari.

Dilihat dari faktor-faktor yang mempengaruhi kerja enzim diatas, maka besar kemungkinan terdapat peningkatan atau penurunan hasil, karena pada saat penelitian ini yang diukur hanya suhu dan lama penyimpanan reagen.

Suhu mempengaruhi aktivitas katalis enzim. Diluar suhu optimum aktivitas enzim menjadi tidak maksimal. Bila suhu terlalu rendah, enzim menjadi tidak aktif, karena tidak terjadi benturan antara molekul enzim dengan substrat. Sedangkan bila suhu terlalu tinggi, dimana benturan yang terjadi semakin banyak maka struktur 
dari enzim akan terganggu sehingga enzim akan mengalami denaturasi, atau dapat dikatakan enzim akan kehilangan sifat alamiahnya.

$\mathrm{pH}$, umumnya enzim efektifitas maksimum pada $\mathrm{pH}$ optimum, yang lazimnya berkisar $6,5-7,0$. Pada $\mathrm{pH}$ yang terlalu tinggi atau terlalu rendah umumnya enzim menjadi non aktif secara irreversibel karena menjadi denaturasi protein.

Konsentrasi enzim, seperti pada katalis lain kecepatan suatu reaksi yang menggunakan enzim tergantung pada konsentrasi enzim tersebut. Pada suatu konsentrasi substrat tertentu, kecepatan reaksi bertambah dengan bertambahnya konsentrasi enzim.

Konsentrasi substrat, hasil eksperimen menunjukkan bahwa dengan konsentrasi substrat akan menaikkan kecepat reaksi. Akan tetapi, pada batas tertentu tidak terjadi kecepatan reaksi, walaupun konsentrasi substrat diperbesar.

Zat-zat penghambat, hambatan atau inhibisi suatu reaksi akan berpengaruh terhadap penggabungan substrat pada bagian aktif yang mengalami hambatan. Suatu enzim hanya dapat bekerja spesifik pada suatu substrat untuk suatu perubahan tertentu (Kurniawan, F. B. 2014).

\section{KESIMPULAN}

Dari hasil penelitian yang telah dilakukan dapat ditarik kesimpulan bahwa lama penyimpanan reagen enzim 1a pada suhu ruangan berpengaruh terhadap hasil pemeriksaan kadar ureum dalam serum dengan menggunakan metode Berthelot dan alat fotometer dimana nilai $F_{\text {hitung }}$
$(44,48)>F$ tabel $(5,14)$. Berarti ho ditolak dan Ha diterima.

\section{SARAN}

Untuk petugas laboratorium perlu diperhatikan reagen kerja yang digunakan, serta lama penyimpanan reagen kerja tidak boleh disimpan terlalu lama karna akan mengalami kerusakan pada dan kesalahan terhadap hasil pemeriksaan yang dikeluarkan oleh petugas laboratorium.

\section{UCAPAN TERIMA KASIH}

Pihak Analis Kesehatan Poltekkes Kemenkes Makassar.

\section{DAFTAR PUSTAKA}

Alam, S., \& Hadibroto, I. 2007. Gagal Ginjal. Jakarta: PT Gramedia Pustaka Utama.

Andriyani, R., Triana, A., \& Juliarti, W. 2015. Biologi Reproduksi dan Perkembangan. Yogyakarta: Deepublish.

Ariffriana, D., Taher, E., \& Wahidah, N. I. 2016. Kimia Klinik. Jakarta: Buku Kedokteran.

Alfiyani, R. 2017. Jurnal Praktikum Analitik III Spektrofotometer UV-Vis.

(http://www.academia.edu/325 06712/JURNAL_PRAKTIKU M_ANALITIK_III_SPEKTRO SKOPI_UV-VIS, diakses 02 Desember 2017).

Baradero, M., Dayrit, M. W., \& Siswadi, Y. 2008. Klien Gangguan Ginjal. Jakarta: Buku Kedokteran.

Bashar, L. Y. 2012. Makalah Instrumentasi Spektrofotometer. 
(http://www.atlm.web.id/2013/ $\underline{04 / m a k a l a h-}$ spektrofotometer.html, diakses 04 Desember 2017).

Bastiansyah, E. 2008. Panduan Lengkap Membaca Hasil Tes Kesehatan. Jakarta: Penebar Plus.

Depkes RI, 2008. Pedoman Praktik Laboratorium Kesehatan Yang Benar (Good Laboratory Practice). Jakarta: Departemen Kesehatan.

Elsa. $2016 . \quad$ Jenis-jenis spektrofotometer dan fungsinya. (https://news.labsatu.com/jenisjenis-spektrofotometer-danfungsinya/, diakses 06 Desember 2017).

Gandjar , I. G., \& Rohman, A. 2007. Kimia Farmasi Analisis. Yogyakarta: Pustaka Pelajar.

Hartono, R. 2018. Penuntun Statistik. Politeknik Kesehatan Makassar Jurusan Analis Kesehatan.

Hurustiaty, dan Mawar .2013. Pengaruh Lama Penyimpanan Reagen Kerja Terhadap Hasil Penetapan Kadar Kreatinin Metode Jaffe Tanpa Deprotenisasi. Makassar: Jurnal Media Analis Kesehatan.

Kurniawan, F. B. 2014. Kimia Klinik. Jakarta: Buku Kedokteran.

Kalma, Herman, Naim, N., \& Bakhri, S. 2015. Panduan Penulisan Skripsi. Makassar: Politeknik Kesehatan Makassar Jurusan Analis Kesehatan.

Laksana, R. P. 2016. Petunjuk Teknis Pengoperasian Alat Spektrofotometer UV-Vis. (www.biomaterial.lipi.go.id/sig ap/wp.../Instruksi-Kerjaspektrofotometer-uv-vis.pdf, diakses 04 Desember 2017)

Nanda, N. T. 2015. Analisa Kadar Ureum Dalam Serum Penderita TB Paru. (http://103.15.241.30/opac/uplo aded_files/dokumen_isi/Monog raf/12034119_001.pdf, diakses 30 November 2017).

Sloane, E. 2012. Anatomi dan Fisiologi untuk Pemula. Jakarta: Buku Kedokteran.

Verdiansah. 2016. Pemeriksaan Fungsi Ginjal.

(www.cdkjournal.com/index.p $\mathrm{hp} / \mathrm{CDK} /$ article/download/25/2 3, diakses 06 Desember 2017) 